\title{
REGIONAL RECAPTURES OF BATS (CHIROPTERA, VESPERTILIONIDAE) RINGED IN EASTERN UKRAINE
}

\author{
A. Vlaschenko ${ }^{1,6^{*}}$, A. Prylutska ${ }^{1,6}$, K. Kravchenko ${ }^{1,3,6}$, O. Rodenko ${ }^{1,2,6}$, V. Hukov ${ }^{1,5,6}$, \\ O. Timofieieva ${ }^{1,4}$, O. Holovchenko ${ }^{1,6}$, M. Moiseienko ${ }^{1,6}$, V. Kovalov ${ }^{1,4,6}$ \\ ${ }^{1}$ Bat Rehabilitation Center of Feldman Ecopark, Lesnoye vil., Kharkiv Region, 62340 Ukraine \\ ${ }^{2}$ Department of Biology and Environmental Protection, University of Silesia in Katowice, \\ Jagiellonska st., 28, Katowice, 40-032 Poland \\ ${ }^{3}$ Leibniz Institute for Zoo and Wildlife Research, Alfred-Kowalke-Straße 17, Berlin, 10315 Germany \\ ${ }^{4}$ Institute of Environmental Sciences, Faculty of Biology, Jagiellonian University, Gronostajowa st. 7, Krakow, \\ 30-387 Poland \\ ${ }^{5}$ Biological department, V. N. Karazin Kharkiv National University, Svobody sq., 4, Kharkiv, 61077 Ukraine \\ ${ }^{6}$ Ukrainian Independent Ecology Institute, Plekhanov st., 40, Kharkiv, 61001 Ukraine \\ ${ }^{*}$ Corresponding author \\ E-mail: anton.vlaschenko@gmail.com
}

Regional Recaptures of Bats (Chiroptera, Vespertilionidae) Ringed in Eastern Ukraine. Vlaschenko, A., Prylutska, A., Kravchenko, K., Rodenko, O., Hukov, V., Timofieieva, O., Holovchenko, O., Moiseienko, M., Kovalov, V. - Bats are volant and highly mobile mammals that could cover up to $2000 \mathrm{~km}$ seasonally (one-way migration). But the level of mobility among different roosts sites in a breeding season, and among breeding areas and hibernation sites is poorly studied. With this communication, we aimed to present results of recaptures (51 cases with a distance of $0.5 \mathrm{~km}$ and more) of bats ringed in Kharkiv Region, Ukraine, from 2006 to 2018. The recaptures were obtained of three main study areas (NNP "Homilsha Forests" - 17 cases, Izium District - 5, Kharkiv City and surroundings 27 ) and at two other localities of the Kharkiv Region. One recapture was obtained in Lugansk Region. The recaptures were received for five bat species (Nyctalus noctula-35, Myotis daubentonii- 11, Eptesicus serotinus -1 , Pipistrellus nathusii -1 and Pipistrellus pygmaeus -3 ). The maximum distances were obtained to different species as follow N. noctula $-209.7 \mathrm{~km}$, M. daubentonii -24.8 , E. serotinus $14.5 \mathrm{~km}, P$. nathusii $-1.1 \mathrm{~km}$ and P.pygmaeus $-1.2 \mathrm{~km}$. For the first time, we confirmed that N. noctula that were born in forested areas of Kharkiv City surroundings moved to the built-up area of the city for hibernation. It is the first direct evidence of the existence of the resident population of this species in Ukraine.

Key words: short-distant movements, banding, migratory patterns, monitoring, bats, Ukraine. 


\section{Introduction}

Bats have complex spatiotemporal population structure, which implies sex and age groups segregation during an annual cycle (e. g.: Strelkov, 1999; Rakhmatulina, 2000; Russo, 2002; Ibáňez et al., 2009). At temperate latitudes with pronounced seasonality, bats need roosts with different microclimate during breeding and hibernation. To find appropriate habitats, bats perform regional or long-distance migration between summer and winter grounds (Hutterer et al., 2005; Steffens et al., 2004; Weller et al., 2016; Voigt et al., 2017). Considering a high conservation priority of bats, information about spatial population structure and seasonal movements is pivotal for providing effective conservation management strategy. However, we still have scarce knowledge about their habitat use, especially on vast territories of Eastern Europe. Despite the fact that new technologies (such as GPS tagging) have provided insights into individual bat movements (e. g. Weller et al., 2016; Roeleke et al., 2016), ringing (or banding) so far remains a classic and comparably cheap method for studying bat movements on the middle- and long-distance spatial scales and over long time periods. Many papers (reviewed in: Hutterer et al., 2005; Steffens et al., 2004) summarized results of recaptures of ringed bats in Europe. They presented the information about the main directions of bat seasonal movements, long-distance and regional migratory patterns, as well as average and maximum distances for different species (Hutterer et al., 2005; Steffens et al., 2004). Data from Eastern European countries (the former Soviet Union) had contributed that reviews significantly, especially in the case of long-distance bat movement with data available up to the end of the 1980th (Panutin, 1980). Later, big-scale bat ringing programs in the Soviet Union were stopped, and for the last ten years, only one long-distant recapture of a bat had been reported from the territory of Ukraine, Russia and Belarus (Gashchak et al., 2015). However, the movement pattern of bats in the Eastern European countries could differ compared to well-studied Western European countries, according to a more continental climate on the East. In this way, data on bat movements from the East could contribute to the whole picture of movement patterns of species. The bat ringing program in Kharkiv Region has been running since 2002 (Vlaschenko, 2012) with more than 20000 individuals of 13 bat species have been ringed until 2018 (unpublished). Previously, we presented results on longevity, local recapture (year by year in one roost), and few short-distance (or regional) recaptures (Vlaschenko, 2012; Vlaschenko et al., 2017). Since 2012, when the first review was published (Vlaschenko, 2012), we had obtained more information about regional recaptures (more than $0.5 \mathrm{~km}$ ) of bats in the Region and aimed to summarize these results in this communication. These data are important for several reasons: 1) documentation of results of the ringing program; 2) better understanding the pattern in bat space use during an annual cycle; 3) present data on direction and distance of bat movements from Eastern Europe.

\section{Material and methods}

Study area and study sites

The main region of the bat ringing program is Kharkiv Region $\left(49^{\circ} 37^{\prime} \mathrm{N} 36^{\circ} 22^{\prime} \mathrm{E}\right.$ ) (all recaptures but one were reported from this territory) that covers 31.4 thousand $\mathrm{km}^{2}$ in north-eastern Ukraine. There is a border between forest-steppe (to the North) and steppe (to the South) nature zones in the southern part of the region. The terrain of the Kharkiv Region is plains area with a maximal elevation of $236 \mathrm{~m}$ above sea level in the north and minimal elevation of $90 \mathrm{~m}$ in the south-east. The mean annual temperature in the region is $8.1{ }^{\circ} \mathrm{C}$, the mean January and July temperatures are $-7{ }^{\circ} \mathrm{C}$ and $+21^{\circ} \mathrm{C}$ respectively, and annual precipitation does not exceed $540 \mathrm{~mm}$. There are oak, pine and mixed forests covering $12 \%$ of the Region (Golikov et al., 2011); the detailed map of bat research in forested areas in the Region is presented in V. Kovalov et al., 2019.

There were three main research polygons where the majority of bats were ringed over several years: Kharkiv City area and surroundings (including Liptsy mines), National Nature Park (NNP) "Homilsha Forests”, Izium District. We visualized main recaptures on five maps according to species and territories (fig 1).

In this paper we use division of an annual bat cycle according to our previous results of a year-round monitoring of bats: period of spring migration (SM) - April 1st - 30th, breeding (B) May 1st - July 31st, autumn invasion or migration (swarming) (AI) August 1 st - September 15th, autumn silence (AS) September 16th - end of October (preliminary), hibernation (H) November (preliminary) - March 31st (Kravchenko et al., 2017 a).

\section{Bat ringing and recapture}

During warm seasons of a year, in areas outside of the Kharkiv City (urban built-up areas), bats were caught by mist-nets and a plastic-trap. In the city area, bats were found in distinct buildings. For more information about methods of bat catching and seasons of study 


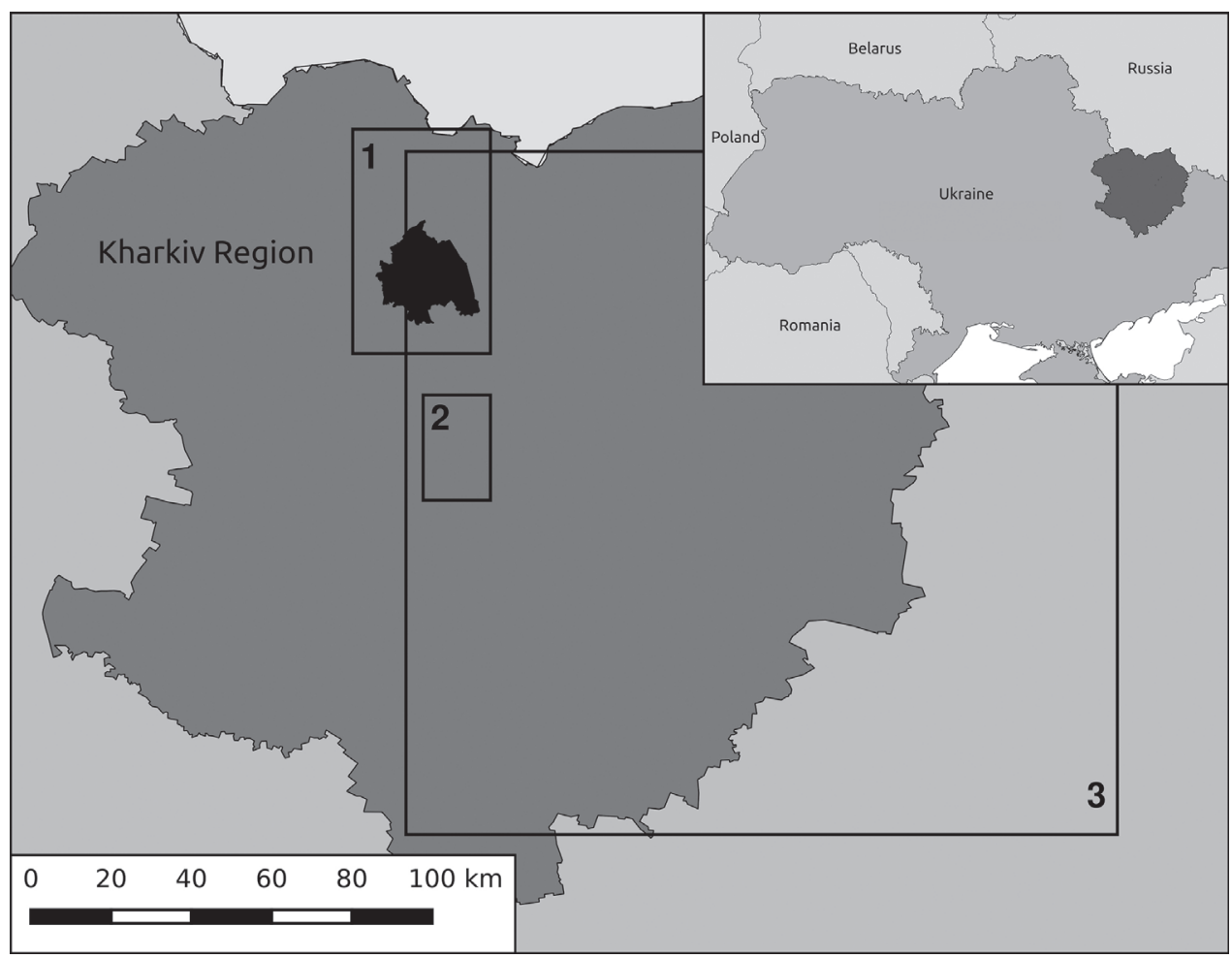

Fig. 1. Map of Kharkiv Region with territories of main recaptures: 1 - recaptures within Kharkiv City and surroundings; 2 - recaptures in NNP "Homilsha Forest"; 3 - recaptures outside of Kharkiv Region.

in forested areas see: Kovalov et al., 2019; Vlaschenko et al., 2016; Gukasova, Vlaschenko, 2011; for more information about the methods applied in the city area see: Kravchenko et al., 2017 a, and in Liptsy mines' area see: Vlaschenko, Naglov, 2018. We distinguished two age groups of bats: ad = adult (specimens older than 1 year), and sad = subadult or 1 styear individuals (specimens younger than 1 year) (details of bats age identification see: $\mathrm{K}$. Kravchenko et al., 2017 a). Specimens of an unclear age were classified as uncertain (un).

We used two types of aluminium rings during the whole period of the ringing program. At the first stage, in 2002-2009, bats were ringed with ornithological rings, which have sharp edges and were operated manually by a nail file. Since 2010 , we started to use special bat-friendly rings. There are five series of rings for different size classes of bats. Each ring has a unique five-digit number and series-specific code: AT (internal diameter 2,4 mm), BT $(2,9 \mathrm{~mm})$, CT $(3,2 \mathrm{~mm})$, DT $(4,2 \mathrm{~mm})$ and ET $(5,2 \mathrm{~mm})$. In addition, each ring has information about the ringing centre and country of ringing ("Kiev, Ukraine"). All types of rings were manufactured by Polish company "Aranea” (Vlaschenko, 2012). We applied previously recommended way of wearing rings (Panutin, 1980): on the left forearm and the last digits of the number to the outside (Vlaschenko, 2012).

During warm seasons of a year, ringed bats were released at the same place or close to the catching site at the same or following night (e. g. Vlaschenko et al., 2016). In Kharkiv City, during the cold season of a year, bats were kept in rehabilitation centre under artificial hibernation conditions (Kravchenko et al. 2017 a, b) until spring. In spring, all bats were released during a special public event "The Bat Release Fest" at one location in Feldman Ecopark (the North border of Kharkiv City). In some cases, groups of bats, found during wintertime in other cities of Ukraine, were transported to the Bat Rehabilitation Center of Feldman Ecopark and later released at the Feldman Ecopark too (Vlaschenko and Prylutska, 2018) 
All applied methods were ethical and respectful to animal welfare and conservation requirements of protected species, according to international standards (Sikes, 2016) and Ukrainian National Law.

\section{Data analysis or map creation}

The complete list of the recaptures is presented in the Appendix. Three main spatial clusters were created: NNP "Homilsha Forests", Kharkiv City area and surroundings (includes recaptures from Liptsy mines), and remote points were grouped together (Lysychansk and others). The recaptures had been systematized in sections according to spatial locations, one by one, by the date of ringing and/or release. For each spatial cluster, we divided recaptures into two groups: the first group with recaptures during one calendar year and the second group with bats recaptures from one of the following years. We calculated a mean value (X) and standard deviation (SD) for distances of recaptures, for sample size with three and more cases. In addition, we added information about the habitat type. Forested areas were recorded as "Forest" (forest areas within the Kharkiv City were categorised as this habitat type), building areas of Kharkiv and suburbs were noted as "Urban", two other categories: "Mine" and "Pit" included swarming and hibernation sites out of urban areas.

If there were a difference between the place of capture and the place of release, in the list of recaptured bats (Appendix) we presented locations of release also.

Distances between release points and recapture points were measured and all maps were created with a free software QGIS v. 2.18.11.

\section{Results}

\section{General findings}

In total, there are 51 recapture cases (with distance $0.5 \mathrm{~km}$ and more) reported since 2006 for five bat species (Nyctalus noctula - 35, Myotis daubentonii - 11, Eptesicus serotinus -1 , Pipistrellus nathusii -1 and Pipistrellus pygmaeus -3 ). The maximum distances according to species were as follows: N. noctula $-209.7 \mathrm{~km}$, M. daubentonii 24.8 , E. serotinus $-14.5 \mathrm{~km}, P$. nathusii $-1.1 \mathrm{~km}$ and $P$. pygmaeus $-1.2 \mathrm{~km}$. Among the 51 recaptures, 17 cases were reported for the NNP "Homilsha Forests" (N. noctula - 9, M. daubentonii -4 , P. nathusii -1 and P. pygmaeus -3 cases); 5 cases were reported for Izium District ( $N$. noctula $-2, M$. daubentonii -3 cases); 27 cases were reported for Kharkiv City and surroundings (N. noctula -22 , M. daubentonii -4 and E. serotinus -1 cases); and one case of recapture is from Lysychansk town (N. noctula -1$)$ and one is from Rubizhne village (N. noctula - 1) (for details see Appendix).

\section{Recaptures in NNP "Homilsha Forests"}

The detailed visualization of bat recaptures in NNP "Homilsha Forests" is presented in fig. 2, a, b. Among nine individuals of N. noctula recaptured in NNP "Homilsha Forests", five recaptures were reported for one year $(X=1 \pm 0.269 \mathrm{~km}, \min =0.51, \max =1.31)$. For $P$. nathusii, $P$. pygmaeus and $M$. daubentonii, there was only one recapture for each species within one year, with distances in 1.1, 0.99 and $0.5 \mathrm{~km}$ respectively (recaptures N 10, 11 and 12 in the Appendix and fig. 2, b). Maximal distances of recaptures reported for different years were the following: $2.2 \mathrm{~km}$ for $N$. noctula (recaptures $\mathrm{N} 7$ and 8 in the Appendix and fig. 2, b), M. daubentonii - 1.3 (case 17) and P. pygmaeus - 1.2 (recapture N 16).

\section{Recaptures in Kharkiv City and surroundings}

The detailed visualization of bat recapture cases in Kharkiv City and surroundings is presented on fig. 3a, b. 
Among 22 individuals of $N$. noctula (fig. 3, a) which were recaptured in the city area and surroundings, seven cases were reported from one calendar year. Among them, three cases (F sad and $2 \mathrm{M}$ sad) were from forest habitats toward urban area during breeding and autumn invasion periods (recaptures N 18, 19 and 22 in the Appendix) $(\mathrm{X}=8.5 \pm 3.083 \mathrm{~km}, \min =4.2, \max =$ 11.21). Moreover, the recapture N 19, is the case when an individual was born in a forest in the vicinity of Kharkiv and moved to the urban area during an autumn invasion. Two recaptures were recorded for one year ( $M$ sad and $M$ ad) with the opposite direction of migration, from an urban area (according to a location where they were found) to forest habitats (those bats were released in the forest of Feldman Ecopark) (cases: 21 and 24 in the Appendix). These bats were recaptured 13 and $51.4 \mathrm{~km}$ respectively out of hibernation area within the Kharkiv City. In addition, the recapture $\mathrm{N} 24$ with a distance in $51.4 \mathrm{~km}$ is the recapture with the longest covered distance within the Kharkiv Region. Two other cases of one-year recaptures (F sad and M sad; N 20 and 23 in the Appendix) were movements within the built-up area in autumn invasion period both with distance in $5.5 \mathrm{~km}$.

Other 15 cases of $N$. noctula recaptures were with a time period more than a year (recaptures N 25-39 in the Appendix). These individuals were found in three periods: hibernation (six recaptures), autumn invasion (eight recaptures) and breeding (one recapture).

Among these 15 individuals, six bats $(3 \mathrm{~F}$ sad, $4 \mathrm{M}$ sad and $\mathrm{M}$ ad) were released in the urban area and were recaptured in the urban area too. Eight bats out of 15 were released in the forest area and recaptured in Kharkiv City. The last individual was released in the forest area with the recapture in the forest area too. Five individuals were released in the forest area of Feldman Ecopark with 2 individuals ( $\mathrm{F}$ ad and $\mathrm{M}$ ad) been recaptured in the urban area at the next or in two winters (cases: 30, 36 in the Appendix). They moved back to the built-up areas from the point of releasing on 11.2 and $8.5 \mathrm{~km}$ respectively. Three individuals ( $\mathrm{M}$ sad and $2 \mathrm{M}$ ad) were
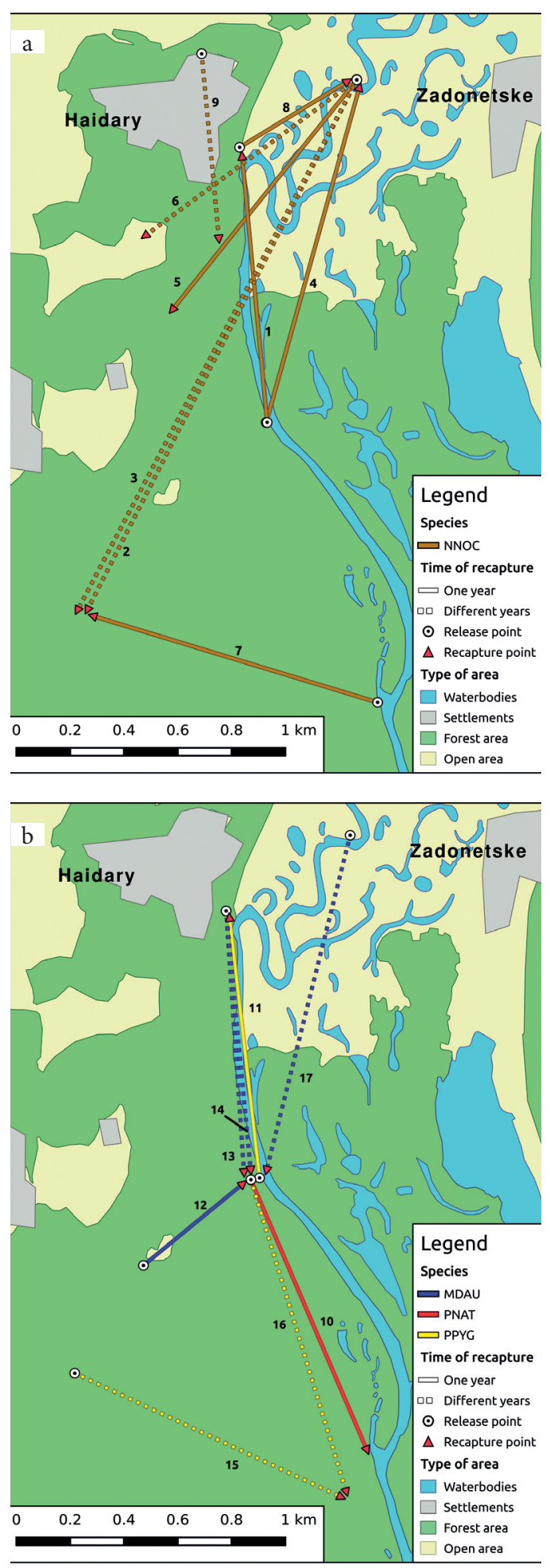

Fig. 2. Detailed map of bat recaptures in NPP "Homilsha Forests" area (research polygon N 2 according to fig. 1): a - recaptures of N. noctula; b recaptures of other species (numbers of the arrows correspond to recapture number in the Appendix). 

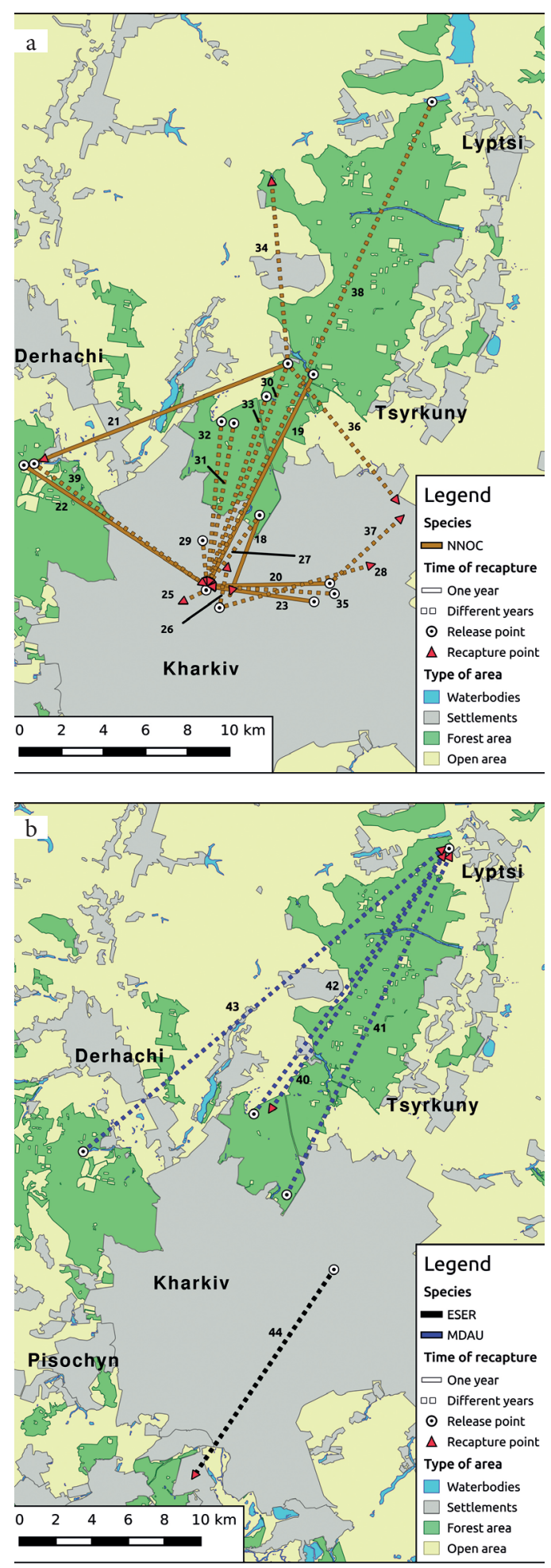

Fig. 3. Detailed map of bat recaptures in Kharkiv City area and surroundings (research polygon $\mathrm{N} 1$ according to fig. 1): a - recaptures of N. noctula; $\mathrm{b}-$ recaptures of other species (numbers of the arrows correspond to recapture number in the Appendix). recaptured in a forested area (cases: 21,24 , 34 in the Appendix, the case 24 see fig. 4) the distances were: $X=24.5 \pm 19.145 \mathrm{~km}$, $\min$ 8.9, $\max =51.4$. In the direction from forest towards city area we have 9 individuals (cases: 18-19, 22, 27, 31-33, 38, 39 in the Appendix). They were caught and ringed in breeding $(\mathrm{n}=$ 2 ) and in autumn invasion $(n=7)$. All of them were recaptured in the urban area in periods of autumn invasion ( $\mathrm{n}=3 ; 2 \mathrm{~F}$ sad, $\mathrm{M}$ sad), hibernation ( $\mathrm{n}=4$; F ad, $3 \mathrm{M}$ sad) and spring migration ( $\mathrm{n}=2 ; 2 \mathrm{M}$ ad), in a distance: $\mathrm{X}=$ $10 \pm 5.902 \mathrm{~km}, \min =4, \max =25.2$.

The recaptures for different sexes of N.noctula in Kharkiv City and surroundings were as follows: females ( $\mathrm{n}=$ $7)-\mathrm{X}=7.5 \pm 3.43 \mathrm{~km}(\min =1.2, \max =$ 11.2); males $(\mathrm{n}=15)-\mathrm{X}=10.9 \pm 12.18 \mathrm{~km}$ $(\min =0.6, \max =51.4)$.

Besides $N$. noctula, we recaptured five individuals of other species in Kharkiv City and surroundings: $M$. daubentonii $(\mathrm{n}=4)$ and E. serotinus $(\mathrm{n}=1)$ (fig. 3, b). One recapture case of E. serotinus ( $\mathrm{F}$ ad, case 44 in the Appendix) was obtained between the centre of the urban area and outskirts (14.5 km) (fig. 3, b). Among $4 \mathrm{M}$. daubentonii recaptures, one (case: 40 in the Appendix) had been described in the previous paper (Vlaschenko, 2012) already. This and other recaptures (cases: 41-43 in the Appendix) of M. daubentonii were movements between bat hibernaculum in Liptsy mines and surrounding forests, some of them were inside the administrative borders of Kharkiv City (fig. 3, b). In one case (case: 43 in the Appendix) we confirmed that an individual of $M$. daubentonii was born in a forest $24.8 \mathrm{~km}$ far from the Liptsy mines and moved there for hibernation. The mean of distance of all movements of $M$. daubentonii is $\mathrm{X}=20.0 \pm 3.06 \mathrm{~km}, \min =17.2, \max =24.8$.

\section{Recaptures in Izium District}

Five recapture cases (M.daubentonii 3; N. noctula - 2) were obtained in Izium District in two research locations in breeding and autumn invasion period; all of them had been described in the previous paper (Vlaschenko, 2012) already (cases: 45-49 in the Appendix). M. daubentonii covered $\mathrm{X}=1 \pm 0.628 \mathrm{~km}, \min =0.6, \max =$ 1.9 , inside one woodland area and between 
summer breeding area and autumn swarming location. Two $N$. noctula covered 0.7 and 1 $\mathrm{km}$ inside one forested area during the breeding period.

Recapture form Lysychansk town and Rubizhne village

Two recaptures of N. noctula, (case: 50 in the Appendix, fig. 4), were from territories far distant from the main research polygons (case: 51 in the Appendix, fig. 4). The first case is the recapture from Lysychansk town $209.7 \mathrm{~km}$ far from the point of releasing in Feldman Ecopark. That individual was from a group of N. noctula rescued in Lysychansk town December 8, 2016, and transported to Bat Rehabilitation Center in Kharkiv, they were rehabilitating all the winter and released in the nature in the vicinity of Kharkiv City.

The recapture case number 51 (Rubizhne village) is $3.9 \mathrm{~km}$ movement of subadult male inside one forested area in the breeding period.

\section{Discussion}

The new set of bat recaptures (presented in this paper) is a significant contribution to knowledge about annual spatiotemporal bat occurrence in the forest-steppe zone in Ukraine. In the period of 1939-1990, only 4003 bats were ringed (Godlevska, 2001) from the territory of Ukraine, and the total number of long-distance, regional and sedentary recaptures were less than ten cases (Hutterer et al., 2005). Previously reported the longest bat recapture ( $P$. pipistrellus s. 1 ., distance $1123 \mathrm{~km}$ ) was from the territory of Central Ukraine to Bulgaria in 1960th (Hutterer et al., 2005). The other recaptures in that period were obtained from the Western border of Ukraine to Hungary, Poland and Slovakia with distances from 27 to $270 \mathrm{~km}$ for Myotis species and up to $200 \mathrm{~km}$ for N. noctula (Hutterer et al., 2005). The most recent (in 2014) recapture of N. noctula from Northern part of

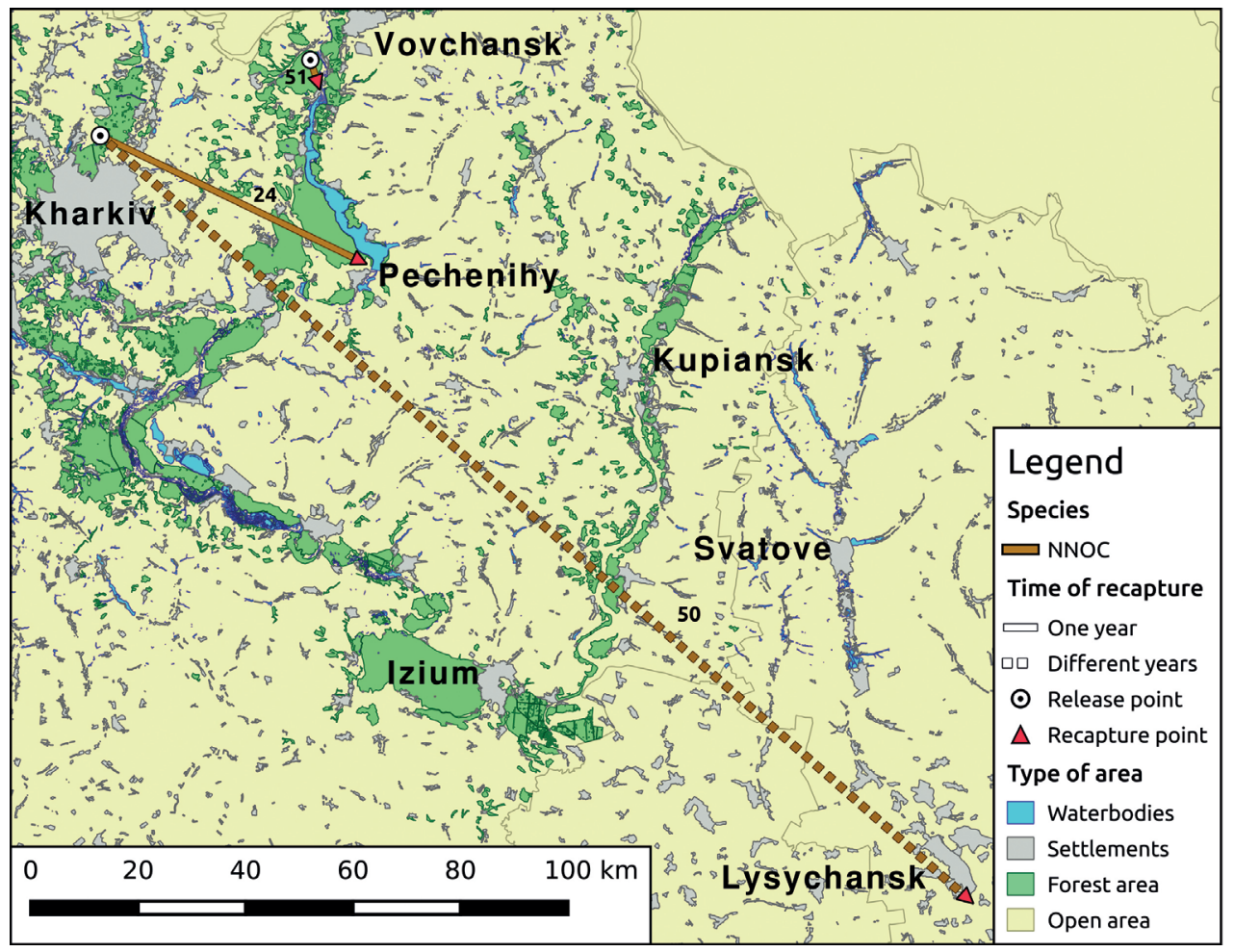

Fig. 4. Map of recaptures of N. noctula in Kharkiv Region (recaptures N 24 and 51), and the farthest recapture (N 50) from Kharkiv Region to Luhansk Region (research polygon N 3 according to fig. 1). 
Central Ukraine to Hungary was with a distance of $800 \mathrm{~km}$ (Gashchak et al., 2015). In this communication we contributed data for the territory of Ukraine by such distances: more than $200 \mathrm{~km}-1$ case, more than $50 \mathrm{~km}-1$ case, on a range of distances $49-20 \mathrm{~km}-$ 3 cases, $19-10 \mathrm{~km}-8$ cases, $9-1 \mathrm{~km}-25$ cases, less than $1 \mathrm{~km}-13$ cases. On the base of our sample size, there were no differences in sex and age-based recapture distances.

Species spatial exploration and utilisation requirements have to be taken into account for developing sustainable conservation programs. Ukraine is still far behind from Central and Western European countries by the number of bat conservation actions, monitoring programs, research and conservation projects, etc. The data about bat movements on the local scale is needed for planning of borders and sizes of nature protected areas and developing local Bat Conservation Action Plans. Our results from NNP "Homilsha Forests", Izium District and Rubizhne village (recaptures in forested areas in breeding season) reveal information about the spatial distribution of bats in a breeding period. The results already obtained for N. noctula, M. daubentonii and Pipistrellus spp. showed that individual home range polygons for these species cover tens and hundreds of square kilometres (e. g. Boye, Dietz, 2005; Roeleke et al., 2016). From this point of view, our data is not new. At the same time, results from NNP "Homilsha Forests", for multiple years (cases 6-9 and 13-17 in the Appendix) indicate a long-term (maximum 7 years) inhabiting of this forest by bats during a breeding season. This confirms that conservation management applied for the area of the NNP "Homilsha Forests" is important for the protection of local bat populations and need to prolong it in the future.

Two of our field-research projects were aimed to find spatial connection between summer (breeding) areas and winter roost locations of $M$. daubentonii and some other resident species (see Acknowledgements). In fact, in this paper, we have presented two cases, for $N$. noctula and M. daubentonii, when a bat was born in a forested area close to hibernaculum and later moved there for overwintering. In the case of M. daubentonii (recapture case: 43 in the Appendix) an individual covers near $25 \mathrm{~km}$ from forest named Karavan (Dergachy District) to Liptsy mines. Liptsy mines are only one known place of mass winter aggregation of $M$. daubentonii for all Kharkiv Region and surroundings (Vlaschenko, Naglov, 2018), and seasonal movement of a bat to that mines is predictable. In opposite, in Karavan Forest the relative abundance of $M$. daubentonii is very low, 10-15 \% (Kovalov et al., 2019; Hukov et al., 2019) and it was a very little chance that one of just tens ringed individuals would be recaptured. This recapture is an important argument for keeping the Karavan Forest under protection.

The most interesting results presented in this paper belong to the recaptures of N. noctula in Kharkiv City area and surroundings. In the middle of XX century, this species was estimated as long-distance migratory species (Abelentsev et al., 1956) in the European part of the former Soviet Union, with main SW direction of autumn migration, that could move up to $1500 \mathrm{~km}$ (Hutterer et al., 2005). But in a short period of time, from the end of 1980th until the end of 1990th, N. noctula changed the migratory strategy and formed numerous winter aggregations in urban areas of Eastern Europe (Strelkov, 2002; Godlevska, 2015). This process of changing of migratory behavior of $N$. noctula was monitored with high precision exactly in Kharkiv City. The first record of individual of this species in wintertime was done in 1986 (Vlaschenko, 2011), after a short gap in monitoring (1991-1998) since 1999 this species became the most numerous in wintertime in the city (Vlaschenko, 1999; Kravchenko et al., 2017 a). But the origin of these hibernating N. noctula was unclear. On the one hand, they could be long-distance migratory individuals that breed up to $1200 \mathrm{~km}$ far north (the northern border of the breeding range of N. noctula, S. Bogdarina, Stelkov 2003). In this case, $N$. noctula is still recognized as long-distance migratory species. On the other hand, these bats could be born in the vicinity of those cities, and in that case, we are observing the formation of sedentary populations at the northern part of hibernation range. Recaptures of individuals from forested area to Kharkiv City area (fig. 3, a) are the 
first evidence of existing sedentary population (or as a minimum a group) of N. noctula in a recently colonized part of a winter range of the species. The recapture data from cities (Kharkiv, recapture case: 25, 26, 30, 36, 37 in the Appendix) (Lysychansk, case 50 in the Appendix) indicates species winter ground fidelity in urban environments and long-term (Vlaschenko et al., 2017) usage of the cities during autumn invasion and hibernation seasons. Likewise in spite of the many existing threats for bats in the urban environment (e. g. Russo and Ancillotto, 2015; Kravchenko et al., 2017 a; Vlaschenko et al., 2019) the home fidelity for hibernation sites in the cities suggest that maybe hibernation could be successful year by year. Moreover, N. noctula uses all the heterogeneous landscape of urban area and surrounding during one period of a bat life cycle, in different periods and in different years. From this point of view such "new" kind of migratory status and spatial occurrence (compare to simple migration between summer and winter habitats) more vulnerable to human activity, and could be a part of ecological trap for this species (Vlaschenko et al., 2019). Vice versa, the heterogeneity of urban landscape (different kinds of roost sites, unfrozen waterbodies in wintertime, street-lights attracting insects, short-distance to city periphery with natural vegetation for air-hawking bat species) could promote species survival by providing diverse possibilities for roosting and feeding on shorter distances. In any case, the "new" type of spatial-temperate population structure of $N$. noctula raises a new level of responsibilities from people towards urban bats (Kravchenko et al., 2017 a; Vlaschenko et al., 2019). Both, non-governmental organizations and governmental authorities should provide more bat education, conservation and rescue actions in cities.

When we started the ringing program in 2002 we expected to get long-distance recaptures of $N$. noctula (Vlaschenko, 2012) by analogy with results from Voronezh Reserve (Voronezh Region, Russia) (Panutin, 1980; Hutterer et al., 2005). At first, the absence of long-distance recaptures we interpreted by the low research activity in regions of potential winter stay (Crimea Peninsula, Caucasus, Balkans and etc.) of the species (Vlaschenko, 2012). However, our regional recaptures mostly support the hypothesis that the absence of long-distance recaptures could be the result of forming the real sedentary population of N. noctula. Moreover, the results of stable isotope analysis (Kravchenko et al., 2018) indicated that in winter aggregation of N. noctula, the proportion of long-distance migrants decrease, in favour of the increasing proportion of locally-born bats for last 12 years.

On the one hand, these 51 regional recaptures are not a big number, considering the time and resources consumed. However, these results are unique for the territory of Ukraine and even for the most territory of the former Soviet Union countries. Therefore, in our opinion, the bat ringing programme has to be continued. There are preliminary $5000-7000$ bats that already wearing rings and live in the surroundings of Kharkiv and the region. The research objective is to intensify observations of these bats, involving additional techniques, as telemetry and GPS tagging for getting new data about spatial population structure.

We thank Pavel Vlaschenko (Krylov), Anton Biatov, Dr. Yegor Yatsuk, Maryna Krivoshyzha, Dr. Oleg Prylutsky, Daria Yelagina, Dr. Alexander Naglov, Yegen Nagorny, Dr. Stanislav Viter, Maria Sudakova, Sergey Saprykin, Olexander Klochko, Natalia Shaniuk, Margarita Moiseenko, Olexey Parfilov, Hanna Suvorova, Volodymir Shuvaev, Anastasia Domanska, Mikhail Shlakhter and all the others for assistance in field work and bat rescue in city area in different periods of this long-term activity. Our special thanks to and Dr. Anatoliy Poluda Head of the Ukrainian Bird Ringing Center, and to Dr. Olena Godlevska for sharing the information about record of ringing Noctula from Lugansk region.

During all long-term period of the ringing program buying of the rings, field expeditions and work in Kharkiv City were supported by the following foundations: Bat Conservation International $(2002,2006,2012)$, projects "The role of nest building activity of woodpeckers in creation of tree-roost suitable for bats in oak forests in Kharkov Region, Ukraine", "Key Role of Bat Hibernation Sites in Deep Rock Crevices for Their Conservation on a Territory without Natural Caves, North-Eastern Ukraine", "Bat Migration and Development of Wind Energy in Ukraine"; The Youth Activity Fund of the Explorers Club $(2003,2014,2016)$ projects "Roost ecology of forest-dwelling bats in the Kharkov Region, Ukraine", "Investigation on bat White-Nose Syndrome fungus, swarming and hibernation of East European bats" and "Searching for birth-place: determination of connection between summer and winter locations of threatened bat populations"; The Rufford Foundation 
(2010, 2012, 2015, 2017), projects 10155-1 “The International Year of Forests in the Northeastern Ukraine: establishing of long-term program on forest biodiversity conservation", 12176-2 "Greater Noctule (Nyctalus lasiopterus) in the Eastern Europe: inventory of current status, proposals to revise the species status in IUCN Red List and conservation", 18147-1 "Shared House: Development of Long-Lasting Conservation Strategy of Urban Bat Habitats in Developing Countries of the Eastern Europe", 21319 "Key bat hibernacula in NorthEastern Ukraine: conservation, population research and monitoring". The International Charity Fund "Oleksander Feldman Foundation" (2013-till now) project The Bat Rehabilitation Center of Feldman Ecopark; The EUROBATS Project Initiative $(2013,2017)$, projects "Kharkov bat education program, Ukraine II" and "Bats across borders: study of south-eastern bat migration way in Eastern Europe”. Special thanks to Dr. Sergey Gashchak and movie-making studio Camera Lucida (France) for financial support in 2009.

\section{References}

Abelentsev, V., Pidoplichko, I., Popov, B. 1956. Order bats.Chiroptera. In: Bilanovsky, I. ed Fauna of Ukraine. Vol. 1.Mammals. Is. 1. Basic characteristic of Mammals. Insectivores, Bats. Vydavnyctvo Akademii nauk Ukrainskoj RSR, Kyiv, 229-446 [In Ukrainian].

Bogdarina, S., Strelkov, P. 2003. Distribution of bats (Chiroptera) in the north of European Russia. Plecotus et al., 6, 7-28 [In Russian with English summary]

Boye, P., Dietz, M. 2005. Development of Good Practice Guidelines for Woodland Management for Bats. Report to The Bat Conservation Trust, 98.

Gashchak, S., Vlaschenko, A., Estok, P., Kravchenko, K. 2015. New long-distance recapture of a Noctule (Nyctalus noctula) from Eastern Europe. Hystrix, the Italian Journal of Mammology, 26 (1), 59-60.

Godlevska, L. 2001. History of bats' migration studying in Ukraine. In: Zagorodniuk, I., ed. Migratsijny status kazhaniv $v$ Ukraini [Migratory status of bats in Ukraine]. NovitatesTheriologicae, pars 6, 29-33 [In Ukrainian with English summary].

Godlevska, L. 2015. Northward expansion of the winter range of Nyctalus noctula (Chiroptera: Vespertilionidae) in Eastern Europe. Mammalia, 79, 315-324.

Golikov, A. P., Kazakova, N. A., Shuba, M. B. 2011. Kharkov region: regional development, current and perspectives. V. N. Karazin Kharkiv National University Press, Kharkiv, 1-329 [In Russian].

Gukasova, A., Vlaschenko, A. 2011. Effectiveness of mist-netting of bats (Chiroptera, Mammalia) during the non-hibernation period in oak forests of Eastern Ukraine. Acta Zoologica Cracoviensia, 54 A (1-2), 77-93.

Hukov, V., Kovalov, V., Suvorova, A., Rodenko, O., Holovchenko, O. 2019. Structure of bat assemblage in an oak forest on the border of a big urban area, with special focus on Great Noctule Bat (Nyctalus lasiopterus Schreber, 1780). Abstracts of the XIV International Young Scientists' Conference, 27-29 November, Kharkiv, Ukraine, 168-169.

Hutterer, R., Ivanova, T., Meyer-Cords, C., Rodrigues, L. 2005. Bat migration in Europe. A review of banding data and literature. Naturschutz und Biologische Vielfalt, 28.Federal Agency of Nature Conservation, Bonn, 1-162.

Ibáňez, C., Guillén, A., Agirre-Mandi, P. N., Juste, J., Schreur, G., Cordero, A. I., Popa-Lisseanu, A. G. 2009. Sexual segregation in Iberian Noctule Bats. Journal of Mammology, 90 (1), 235-243.

Kovalov, V., Hukov, V., Rodenko, O. 2019. New record of Nyctalus lasiopterus (Schreber, 1780) in Ukraine with a new confirmation of carnivory. North-Western Journal of Zoology, 15 (1), 91-95.

Kravchenko, K., Vlaschenko, A., Prylutska, A., Rodenko, O., Hukov, V., Shuvaev, V. 2017 a. Year-round monitoring of bat records in an urban area: Kharkiv (NE Ukraine), 2013, as a case study. 2017. Turkish Journal of Zoology, 41, 530-548.

Kravchenko, K., Vlaschenko, A., Rodenko, O., Hukov, V., Belovetskaya, S. 2017 b. The results of all-winter rehabilitation of Nyctalus noctula: a case study (Kharkiv, NE Ukraine). Abstract of 5 th International Berlin Bat Meeting: "Are bats special?, 24-26 February, Berlin, Germany, 102.

Kravchenko, K., Vlaschenko, A., Lehnert, L., Voigt, C. 2018. Changes in migratory status of bats revealed by stable isotopes. Abstract of Deutsches Treffen fur Fledermausforschung, 12-14 January 2018, Heidesee, Germany, 62 .

Panutin, K. K. 1980. Bats. In: Kucheruk, V. V., ed. Results of Mammals Banding. Nauka, Moscow, 23-46 [In Russian with English summary].

Rakhmatulina, I. K. 2000. Sex ratio in bat populations in the Eastern Transcaucasus. Plecotus et al., 3, $50-76$ [In Russian with English summary].

Roeleke, M., Blohm, T., Kramer-Schadt, S., Yovel, Y., Voigt, C. C. 2016. Habitat use of bats in relation to wind turbines revealed by GPS tracking. Scientific Reports, 6, 28961.

Russo, D. 2002. Elevation affects the distribution of the sexes in Daubenton's bats Myotis daubentonii (Chiroptera: Vespertilionidae) from Italy. Mammalia, 66, 543-551.

Russo, D., Ancillotto, L. 2015. Sensitivity of bats to urbanization: a review. Mammalian Biology, 80 (3), 205-212.

Sikes, R. S. 2016. Guidelines of the American Society of Mammalogists for the use of wild mammals in research and education. Journal of Mammalogy, 97 (3), 663-688.

Steffens, R., Zöphel, U., Brockmann, D. 2004. 40th Anniversary Bat Marking Centre Dresden — Evaluation of Methods and Overview of Results. Saxon State Office for Environment and Geology, Dresden, Germany, 124. 
Strelkov, P. P. 2002. Materials on wintering of migratory bat species (Chiroptera) on the territory of the former USSR and adjacent regions. Part. 2. Nyctalus noctula. Plecotus et al., 5, 35-56 [In Russian with English summary].

Strelkov, P. P. 1999. Sex ratio in breeding season in adult individuals of long-distant migrant bats (Chiroptera, Vespertilionidae) of Eastern Europe and adjacent territories. Zoologicheskiu zhurnal, 78 (12), 1441-1454 [In Russian with English summary].

Vlaschenko, A. S. 1999. Record of hibernated Nyctalus noctula in Kharkov.Vestnik Zoologii, 33 (4-5), 76 [In Russian].

Vlaschenko, A. S. 2011. Research history and list of records of bats (Chiroptera) in the Kharkov Region in the XIX and XIX centuries. Plecotus et al., 14, 26-54 [In Russian with English summary].

Vlaschenko, A. S. 2012. Results of Bat (Chiroptera) Ringing on the Territory of Kharkov Region (2002-2012). Proceedings of the National Museum of Natural History, 10, 31-41 [In Russian].

Vlaschenko, A., Hukov, V., Naglov, A., Prylutska, A., Kravchenko, K., Rodenko, O. 2016. Contribution to ecology of Brandt's Bat Myotis brandtii (Chiroptera, Vespertilionidae), in the North-eastern Ukraine: comparison of local summer and winter bat assemblages. Vestnik Zoologii, 50 (3), 231-240.

Vlaschenko, A., Kravchenko, K., Hukov, V., Prylutska, A., Rodenko, O. 2017. Contribution to bat longevity studies in Ukraine. Abstract of 5th International Berlin Bat Meeting: "Are bats special?", 24-26 February, Berlin, Germany, 58.

Vlaschenko, A., Naglov, A. 2018. Results of the 10-year monitoring of bat (Chiroptera: Vespertilionidae) winter aggregation from the North-eastern Ukraine (Liptsy mines, Kharkiv region). Vestnik Zoologii, 52 (5), 395-416.

Vlaschenko, A., Prylutska, A. 2018. Das Bat Rehabilitation Center des "Feldman Ecoparks". Nyctalus NF, 19 (2), 158-161 [In German].

Vlaschenko, A., Kovalov, V., Hukov, V., Kravchenko, K., Rodenko, O. 2019. An example of ecological traps for bats in the urban environment. European Journal of Wildlife Research, 65, 20.

Voigt, C. C., Frick, W. F., Holderied, M. W., Holland, R., Kerth, G., Mello, M. A. R., Plowright, R., Swartz, S., Yovel, Y. 2017. Principles and patterns of bat movements: From aerodynamics to ecology. The Quarterly Review of Biology, 92, 267-287.

Weller, T. J., Castle, K. T., Liechti, F., Hein, C. D., Schirmacher, M. R., Cryan, P. M. 2016. First Direct Evidence of Long-distance Seasonal Movements and Hibernation in a Migratory Bat. Scientific Reports, 6, 34585.

Received 1 July2019

Accepted 25 October 2019

\section{Appendix}

List of recaptured bats in the Eastern Ukraine on distance more than $0.5 \mathrm{~km}, 2006-2018$ :

A bbreviations: Bat species acronyms: Mdau - Myotis daubentonii; Eser - Eptesicus serotinus; Nnoc Nyctalus noctula; Pnat - Pipistrellus nathusii; Ppyg - Pipistrellus pygmaeus. Symbols of sex and acronyms of age: $\mathrm{F}$ - female; $\mathrm{M}$ - male; ad — adult individual; sad — subadult individual; un — sex and/or age were unidentified. Date of record: 20.02.2008 — dd.mm.yyyy; Geographical coordinates: in decimal values.

Symbols of seasons of a year according to bat life-cycle (Kravchenko et al., 2017a): spring migration - SM (April 1st - 30th); breeding - B (May 1st — July 31st); autumn invasion or migration AI (August 1st - September 15th); autumn silence - AS (September 16th - end of October); hibernation $\mathrm{H}$ (November (preliminary) - March 31st).

Symbols of capture methods: mist-netting - MN; captured from a roost site - R; find in a city - CR.

In the List for some records in Kharkiv City we gave two dates and two seasons, the first data is the day of the record and the second one, in brackets, is the date of release in the Feldman Ecopark area. We divided by semicolons dates, point coordinates, season of a year and type of catching.

\section{National Nature Park "Homilsha forests"}

\begin{tabular}{|c|c|c|c|c|}
\hline $\mathrm{N}$ & $\begin{array}{l}\text { Species and ring } \\
\text { number }\end{array}$ & $\begin{array}{c}\text { Released (captured) } \\
\text { and ringed: date, point } \\
\text { coordinates, season of a year, } \\
\text { type of catching }\end{array}$ & $\begin{array}{c}\text { Recaptured: } \\
\text { date, point coordinates, season } \\
\text { of a year, type of catching }\end{array}$ & Distance, $\mathrm{km}$ \\
\hline \multicolumn{5}{|c|}{ "Homilsha forests" N. noctula one year } \\
\hline 1 & $\begin{array}{c}\text { Nnoc F ad } \\
\text { C006620 }\end{array}$ & $\begin{array}{c}13.07 .2007 ; \\
49.62554 \text { N, } 36.33329 \mathrm{E} ; \\
\text { B; MN. }\end{array}$ & $\begin{array}{c}\text { 14.07.2007; } \\
\text { 49.61782 N, 36.32396 E; } \\
\text { B; MN. }\end{array}$ & 1 \\
\hline
\end{tabular}




\begin{tabular}{|c|c|c|c|c|}
\hline 2 & $\begin{array}{c}\text { Nnoc F sad } \\
\text { ET00043 }\end{array}$ & $\begin{array}{c}\text { 03.07.2008; } \\
\text { 49.62298 N, 36.32732 E; } \\
\text { B; MN. }\end{array}$ & $\begin{array}{c}16.07 .2008 ; \\
\text { 49.62554 N, 36.33329 E; } \\
\text { B; MN. }\end{array}$ & 0,5 \\
\hline 3 & $\begin{array}{c}\text { Nnoc F sad } \\
\text { ET00091 }\end{array}$ & $\begin{array}{c}\text { 05.07.2008; } \\
\text { 49.61411 N, 36.32863 E; } \\
\text { B; MN. }\end{array}$ & $\begin{array}{c}\text { 16.07.2008; } \\
\text { 49.62554 N, 36.33329 E; } \\
\text { B; MN. }\end{array}$ & 1,2 \\
\hline 4 & $\begin{array}{l}\text { Nnoc M sad } \\
\text { DT01277 }\end{array}$ & $\begin{array}{c}\text { 14.07.2011; } \\
\text { 49.61411 N, 36.32863 E; } \\
\text { B; MN. }\end{array}$ & $\begin{array}{c}\text { 18.07.2011; } \\
\text { 49.62298 N, 36.32732 E; } \\
\text { B; MN. }\end{array}$ & 0,8 \\
\hline 5 & $\begin{array}{c}\text { Nnoc M ad } \\
\text { DT01308 }\end{array}$ & $\begin{array}{c}\text { 16.07.2011; } \\
\text { 49.60477 N, 36.33436 E; } \\
\text { B; MN. }\end{array}$ & $\begin{array}{c}\text { 20.07.2011; } \\
\text { 49.60782 N, 36.31909 E; } \\
\text { B; R. }\end{array}$ & 1 \\
\hline \multicolumn{5}{|c|}{ "Homilsha forests" N. noctula different years } \\
\hline 6 & $\begin{array}{l}\text { Nnoc F ad } \\
\text { C006612 }\end{array}$ & $\begin{array}{c}\text { 13.07.2007; } \\
\text { 49.62554 N, 36.33329 E; } \\
\text { B; MN. }\end{array}$ & $\begin{array}{c}04.07 .2008 \\
\text { 49.62517 N, 36.33299 E; } \\
\text { B; R. }\end{array}$ & 0,5 \\
\hline 7 & $\begin{array}{c}\text { Nnoc F sad } \\
\text { C006623 }\end{array}$ & $\begin{array}{c}\text { 13.07.2007; } \\
\text { 49.62554 N, 36.33329 E; } \\
\text { B; MN. }\end{array}$ & $\begin{array}{c}\text { 10.07.2008; } \\
\text { 49.60782 N, 36.31909 E; } \\
\text { B; MN. }\end{array}$ & 2 \\
\hline 8 & $\begin{array}{c}\text { Nnoc F sad } \\
\text { C006623 }\end{array}$ & $\begin{array}{c}13.07 .2007 ; \\
\text { 49.62554 N, 36.33329 E; } \\
\text { B; MN. }\end{array}$ & $\begin{array}{c}20.07 .2011 ; \\
49.60782 \mathrm{~N}, 36.31909 \mathrm{E} \\
\text { B; MN. }\end{array}$ & 2 \\
\hline 9 & $\begin{array}{c}\text { Nnoc } \mathrm{M} \text { ad } \\
\mathrm{C} 006315\end{array}$ & $\begin{array}{c}\text { 12.07.2006; } \\
\text { 49.62641 N, 36.32531 E; } \\
\text { B; R. }\end{array}$ & $\begin{array}{c}01.11 .2013 ; \\
\text { 49.620277 N, 36.326186 E; } \\
\text { In an owl (Strixaluco) pellet }\end{array}$ & 0,8 \\
\hline \multicolumn{5}{|c|}{ "Homilsha forests"other species one year } \\
\hline 10 & $\begin{array}{l}\text { Pnat F sad } \\
\text { BT00131 }\end{array}$ & $\begin{array}{c}\text { 05.07.2008; } \\
\text { 49.61411 N, 36.32863 E; } \\
\text { B; MN. }\end{array}$ & $\begin{array}{c}08.07 .2008 \\
\text { 49.60477 N, 36.33436 E; } \\
\text { B; MN. }\end{array}$ & 1,2 \\
\hline 11 & $\begin{array}{l}\text { Ppyg F ad } \\
\text { AT00143 }\end{array}$ & $\begin{array}{c}\text { 06.07.2011; } \\
\text { 49.61411 N, 36.32863 E; } \\
\text { B; MN. }\end{array}$ & $\begin{array}{c}\text { 18.07.2011; } \\
\text { 49.62298 N, 36.32732 E; } \\
\text { B; MN. }\end{array}$ & 0,8 \\
\hline 12 & $\begin{array}{c}\text { Mdau F sad } \\
\text { BT02091 }\end{array}$ & $\begin{array}{c}\text { 07.07.2011; } \\
\text { 49.61169 N, 36.32319 E; } \\
\text { B; MN. }\end{array}$ & $\begin{array}{c}\text { 07.07.2011; } \\
\text { 49.61411 N, 36.32863 E; } \\
\text { B; MN. }\end{array}$ & 0,5 \\
\hline \multicolumn{5}{|c|}{ "Homilsha forests" other species different years } \\
\hline 13 & $\begin{array}{c}\text { Mdau F ad } \\
\text { A056819 }\end{array}$ & $\begin{array}{c}\text { 13.07.2006; } \\
\text { 49.62298 N, 36.32732 E; } \\
\text { B; MN. }\end{array}$ & $\begin{array}{c}29.04 .2008 \\
\text { 49.61411 N, 36.32863 E; } \\
\text { SM; MN. }\end{array}$ & 0,8 \\
\hline 14 & $\begin{array}{l}\text { Mdau F } \\
\mathrm{A} 05681 ?\end{array}$ & $\begin{array}{c}\text { 13.07.2006; } \\
\text { 49.62298 N, 36.32732 E; } \\
\text { B; MN. }\end{array}$ & $\begin{array}{c}\text { 09.05.2009 } \\
\text { 49.61411 N, 36.32863 E; } \\
\text { B; MN. }\end{array}$ & 0,7 \\
\hline 15 & $\begin{array}{l}\text { Ppyg F ad } \\
\text { BT00236 }\end{array}$ & $\begin{array}{c}10.07 .2008 \\
\text { 49.60782 N, 36.31909 E; } \\
\text { B; MN. }\end{array}$ & $\begin{array}{c}\text { 03.07.2011 } \\
\text { 49.60352 N, 36.33299 E; } \\
\text { B; R. }\end{array}$ & 1 \\
\hline 16 & $\begin{array}{l}\text { Ppyg F ad } \\
\text { BT01921 }\end{array}$ & $\begin{array}{c}29.06 .2009 \\
\text { 49.61411 N, 36.32863 E; } \\
\text { B; MN. }\end{array}$ & $\begin{array}{c}\text { 03.07.2011 } \\
\text { 49.60352 N, 36.33299 E; } \\
\text { B; R. }\end{array}$ & 1,3 \\
\hline 17 & $\begin{array}{l}\text { Mdau F sad } \\
\text { BT00305 }\end{array}$ & $\begin{array}{c}\text { 16.07.2008; } \\
\text { 49.62554 N, 36.33329 E; } \\
\text { B; MN. }\end{array}$ & $\begin{array}{c}\text { 06.07.2011 } \\
\text { 49.61411 N, 36.32863 E; } \\
\text { B; MN. }\end{array}$ & 1,15 \\
\hline
\end{tabular}

\section{Kharkiv City and surroundings}

\begin{tabular}{|c|c|c|c|c|}
\hline № & $\begin{array}{l}\text { Species and ring } \\
\text { number }\end{array}$ & $\begin{array}{l}\text { Released (captured) and } \\
\text { ringed: date, point coordi- } \\
\text { nates, season of a year, type } \\
\text { of catching }\end{array}$ & $\begin{array}{c}\text { Recaptured: } \\
\text { date, point coordinates, season } \\
\text { of a year, type of catching }\end{array}$ & Distance, $\mathrm{km}$ \\
\hline 18 & $\begin{array}{l}\text { Nnoc M sad } \\
\text { DT02064 }\end{array}$ & $\begin{array}{c}\text { N. noctula one year } \\
28.08 .2011 ; \\
\text { 50.03813 N, 36.2542 E } \\
\text { AI; MN. }\end{array}$ & $\begin{array}{c}07.09 .2011 \\
50.004393 \mathrm{~N}, 36.227882 \mathrm{E} ; \\
\text { AI; CR. }\end{array}$ & 4,2 \\
\hline
\end{tabular}




\begin{tabular}{|c|c|c|c|c|}
\hline 19 & $\begin{array}{c}\text { Nnoc F sad } \\
\text { DT06137 }\end{array}$ & $\begin{array}{c}\text { 25.07.2014; } \\
50.09847 \text { N, 36.29302 E } \\
\text { B; MN. }\end{array}$ & $\begin{array}{c}19.08 .2014 ; \\
50.006779 \mathrm{~N}, 36.227137 \mathrm{E} ; \\
\text { AI; CR. }\end{array}$ & 11 \\
\hline 20 & $\begin{array}{l}\text { Nnoc F sad } \\
\text { DT10934 }\end{array}$ & $\begin{array}{c}\text { 22.08.2016; } \\
50.006770 \mathrm{~N}, 36.305709 \mathrm{E} ; \\
\text { AI; CR. }\end{array}$ & $\begin{array}{c}\text { 29.08.2016; } \\
50.006779 \mathrm{~N}, 36.227137 \mathrm{E} ; \\
\text { AI; CR. }\end{array}$ & 5,7 \\
\hline 21 & $\begin{array}{l}\text { Nnoc M sad } \\
\text { DT12527 }\end{array}$ & $\begin{array}{c}\text { 09.03.2017 (25.03.2017); } \\
50.101664 \text { N, 36.280024 E; } \\
\text { H; CR. }\end{array}$ & $\begin{array}{c}02.07 .2017 \\
50.057528 \mathrm{~N}, 36.108639 \mathrm{E} ; \\
\text { B; MN. }\end{array}$ & 13,2 \\
\hline 22 & $\begin{array}{l}\text { Nnoc F sad } \\
\text { DT13920 }\end{array}$ & $\begin{array}{c}\text { 07.08.2017; } \\
\text { 50.057528 N; } 36.108639 \mathrm{E} ; \\
\text { AI; MN. }\end{array}$ & $\begin{array}{c}\text { 29.08.2017; } \\
50.006779 \mathrm{~N}, 36.227137 \mathrm{E} ; \\
\text { AI; CR. }\end{array}$ & 10,2 \\
\hline 23 & $\begin{array}{l}\text { Nnoc M sad } \\
\text { DT12849 }\end{array}$ & $\begin{array}{c}\text { 27.08.2017; } \\
50.006770 \text { N, 36.305709 E; } \\
\text { AI; CR. }\end{array}$ & $\begin{array}{c}\text { 15.11.2017; } \\
\text { 50.006779 N, 36.227137 E; } \\
\text { H; CR. }\end{array}$ & 5,7 \\
\hline \multirow[t]{2}{*}{24} & $\begin{array}{l}\text { Nnoc M ad } \\
\text { DT14951 }\end{array}$ & $\begin{array}{c}\text { 17.01.2018 (14.04.2018); } \\
\text { 50.101664 N, 36.280024 E; } \\
\text { H (SM); CR. }\end{array}$ & $\begin{array}{c}\text { 11.07.2018; } \\
\text { 49.899375 N, 36.933074 E; } \\
\text { B; MN. }\end{array}$ & 52 \\
\hline & & N. noctula different years & & \\
\hline 25 & $\begin{array}{l}\text { Nnoc F sad } \\
\text { ET00459 }\end{array}$ & $\begin{array}{c}\text { 19.11.2008; } \\
\text { 50.006779 N, 36.227137 E; } \\
\text { H; CR. }\end{array}$ & $\begin{array}{c}\text { 06.04.2012; } \\
\text { 50.001437 N, 36.212821 E; } \\
\text { SM; CR. }\end{array}$ & 1,1 \\
\hline 26 & $\begin{array}{l}\text { Nnoc M sad } \\
\text { DT02271 }\end{array}$ & $\begin{array}{c}14.09 .2011 ; \\
50.004393 \mathrm{~N}, 36.227882 \mathrm{E} ; \\
\text { AI; CR. }\end{array}$ & $\begin{array}{c}16.12 .2013 ; \\
50.017328 \mathrm{~N}, 36.235362 \mathrm{E} ; \\
\text { H; CR. }\end{array}$ & 5,2 \\
\hline 27 & $\begin{array}{l}\text { Nnoc M sad } \\
\text { DT04180 }\end{array}$ & $\begin{array}{c}\text { 18.08.2012; } \\
\text { 50.00439 N, 36.22788 E; } \\
\text { AI; MN. }\end{array}$ & $\begin{array}{c}\text { 19.11.2015; } \\
\text { 50.006779 N, 36.227137 E; } \\
\text { H; CR. }\end{array}$ & 4,1 \\
\hline 28 & $\begin{array}{l}\text { Nnoc M sad } \\
\text { DT04311 }\end{array}$ & $\begin{array}{c}\text { 20.11.2012; } \\
50.004393 \text { N, 36.227882 E; } \\
\text { H; CR. }\end{array}$ & $\begin{array}{c}28.03 .2013 \\
50.013462 \mathrm{~N}, 36.340316 \mathrm{E} \\
\text { H; CR; }\end{array}$ & 8,1 \\
\hline 29 & $\begin{array}{l}\text { Nnoc M sad } \\
\text { DT04822 }\end{array}$ & $\begin{array}{c}24.08 .2013 \\
\text { 50.01214 N, 36.22914 E; } \\
\text { AI; CR. }\end{array}$ & $\begin{array}{c}04.03 .2014 \\
\text { 50.038669 N, 36.364256 E; } \\
\text { SM; CR. }\end{array}$ & 0,6 \\
\hline 30 & $\begin{array}{l}\text { Nnoc F ad } \\
\text { DT03682 }\end{array}$ & $\begin{array}{c}25.01 .2014(23.03 .2014) ; \\
50.101664 \text { N, 36.280024 E; } \\
\text { H; CR. }\end{array}$ & $\begin{array}{c}\text { 13.03.2015; } \\
\text { 50.006779 N, 36.227137 E; } \\
\text { H; CR. }\end{array}$ & 11,3 \\
\hline 31 & $\begin{array}{l}\text { Nnoc M sad } \\
\text { DT06346 }\end{array}$ & $\begin{array}{c}07.08 .2014 ; \\
50.0629 \mathrm{~N}, 36.24419 \mathrm{E} \\
\text { AI; MN. }\end{array}$ & $\begin{array}{c}\text { 26.03.2015; } \\
\text { 50.006779 N, 36.227137 E; } \\
\text { H; CR. }\end{array}$ & 7,8 \\
\hline 32 & $\begin{array}{l}\text { Nnoc F ad } \\
\text { DT08062 }\end{array}$ & $\begin{array}{c}\text { 07.08.2014; } \\
\text { 50.07657 N, 36.23601 E } \\
\text { AI; MN. }\end{array}$ & $\begin{array}{c}22.11 .2015 \\
50.006779 \mathrm{~N}, 36.227137 \mathrm{E} ; \\
\text { H; CR. }\end{array}$ & 7,8 \\
\hline 33 & $\begin{array}{l}\text { Nnoc M sad } \\
\text { DT05672 }\end{array}$ & $\begin{array}{c}12.08 .2014 \\
50.08616 \mathrm{~N}, 36.27209 \mathrm{E} ; \\
\text { AI; MN. }\end{array}$ & $\begin{array}{c}\text { 09.03.2015; } \\
\text { 50.006779 N, 36.227137 E; } \\
\text { H; CR. }\end{array}$ & 9,5 \\
\hline 34 & $\begin{array}{l}\text { Nnoc } \mathrm{M} \text { ad } \\
\text { DT08348 }\end{array}$ & $\begin{array}{c}\text { 02.12.2014 (28.03.2015); } \\
\text { 50.101664 N, 36.280024 E; } \\
\text { H; CR. }\end{array}$ & $\begin{array}{c}\text { 04.07.2016; } \\
\text { 50.18124 N, 36.26901 E; } \\
\text { B; MN. }\end{array}$ & 8,8 \\
\hline 35 & $\begin{array}{l}\text { Nnoc M ad } \\
\text { DT07401 }\end{array}$ & $\begin{array}{c}03.11 .2015 \\
50.006770 \mathrm{~N}, 36.305709 \mathrm{E} ; \\
\text { H; CR. }\end{array}$ & $\begin{array}{c}04.04 .2016 \\
\text { 50.006779 N, 36.227137 E; } \\
\text { SM; CR. }\end{array}$ & 5,7 \\
\hline 36 & $\begin{array}{l}\text { Nnoc M ad } \\
\text { DT07564 }\end{array}$ & $\begin{array}{c}06.12 .2015(03.04 .2016) ; \\
50.101664 \text { N, 36.280024 E; } \\
\text { H (SM); CR. }\end{array}$ & $\begin{array}{c}21.12 .2017 \\
50.041748 \text { N, 36.354048 E; } \\
\text { H; CR. }\end{array}$ & 8,5 \\
\hline 37 & $\begin{array}{l}\text { Nnoc F sad } \\
\text { DT10917 }\end{array}$ & $\begin{array}{c}22.08 .2016 \\
50.006770 \mathrm{~N}, 36.305709 \mathrm{E} ; \\
\text { AI; CR. }\end{array}$ & $\begin{array}{c}17.01 .2018 \\
50.038669 \mathrm{~N}, 36.364256 \mathrm{E} ; \\
\text { H; CR. }\end{array}$ & 5,5 \\
\hline 38 & $\begin{array}{l}\text { Nnoc } \mathrm{M} \text { ad } \\
\text { DT10350 }\end{array}$ & $\begin{array}{c}\text { 11.07.2016; } \\
\text { 50.213077 N, 36.375648 E; } \\
\text { B; MN. }\end{array}$ & $\begin{array}{c}\text { 10.04.2018; } \\
\text { 50.006779 N, 36.227137 E; } \\
\text { SM; CR. }\end{array}$ & 25,3 \\
\hline
\end{tabular}




\begin{tabular}{|c|c|c|c|c|}
\hline 39 & $\begin{array}{c}\text { Nnoc M ad } \\
\text { DT13353 }\end{array}$ & $\begin{array}{c}03.08 .2017 \\
50.057528 \mathrm{~N}, 36.108639 \mathrm{E} ; \\
\text { AI; MN. }\end{array}$ & $\begin{array}{c}\text { 01.04.2018; } \\
\text { 50.006779 N, 36.227137 E; } \\
\text { SM; CR. }\end{array}$ & 10,2 \\
\hline \multicolumn{5}{|c|}{ Kharkiv other species different years } \\
\hline 40 & $\begin{array}{c}\text { Mdau M sad } \\
\text { B028597 }\end{array}$ & $\begin{array}{c}\text { 29.03.2008; } \\
\text { 50.205333 N, 36.378562 E; } \\
\text { H (SM); MN. }\end{array}$ & $\begin{array}{c}\text { 19.05.2011; } \\
50.07617 \mathrm{~N}, 36.24348 \mathrm{E} \\
\text { B; MN. }\end{array}$ & 16 \\
\hline 41 & $\begin{array}{l}\text { Mdau } \mathrm{M} \text { ad } \\
\text { BT02175 }\end{array}$ & $\begin{array}{c}18.08 .2012 ; \\
\text { 50.037204 N, 36.251235 E; } \\
\text { AI; MN. }\end{array}$ & $\begin{array}{c}\text { 26.08.2013; } \\
\text { 50.205333 N, 36.378562 E; } \\
\text { AI; MN. }\end{array}$ & 20,7 \\
\hline 42 & $\begin{array}{l}\text { Mdau } \mathrm{M} \text { ad } \\
\text { BT02255 }\end{array}$ & $\begin{array}{c}\text { 08.08.2014; } \\
\text { 50.07657 N, 36.23601 E; } \\
\text { AI; MN. }\end{array}$ & $\begin{array}{c}24.01 .2013 ; \\
50.205333 \mathrm{~N}, 36.378562 \mathrm{E} ; \\
\text { H; R. }\end{array}$ & 17,4 \\
\hline 43 & $\begin{array}{l}\text { Mdau M sad } \\
\text { BT05174 }\end{array}$ & $\begin{array}{c}\text { 05.07.2017; } \\
\text { 50.058361 N, 36.114222 E; } \\
\text { B; MN. }\end{array}$ & $\begin{array}{c}\text { 01.09.2018; } \\
\text { 50.205333 N, 36.378562 E; } \\
\text { AI; MN. }\end{array}$ & 25 \\
\hline 44 & $\begin{array}{l}\text { Eser F ad } \\
\text { DT10615 }\end{array}$ & $\begin{array}{c}\text { 03.11.2016; } \\
\text { 50.006770 N, 36.305709 E; } \\
\text { H; CR. }\end{array}$ & $\begin{array}{c}\text { 02.03.2017; } \\
\text { 49.898789 N, 36.190837 E; } \\
\text { H; CR. }\end{array}$ & 14,5 \\
\hline
\end{tabular}

\section{Izium District}

\begin{tabular}{|c|c|c|c|c|}
\hline № & $\begin{array}{l}\text { Species and ring } \\
\text { number }\end{array}$ & $\begin{array}{l}\text { Released (captured) and } \\
\text { ringed: date, point coordi- } \\
\text { nates, season of a year, type } \\
\text { of catching }\end{array}$ & $\begin{array}{c}\text { Recaptured: } \\
\text { date, point coordinates, season } \\
\text { of a year, type of catching }\end{array}$ & Distance, $\mathrm{km}$ \\
\hline 45 & $\begin{array}{c}\text { Mdau M sad } \\
\text { A056832 }\end{array}$ & $\begin{array}{c}\text { 20.07.2006; } \\
\text { 49.181361 N, 37.011481 E; } \\
\text { B; MN. }\end{array}$ & $\begin{array}{c}24.07 .2006 ; \\
\text { 49.173819 N, 36.986781 E; } \\
\text { B; MN. }\end{array}$ & 3 \\
\hline 46 & $\begin{array}{l}\text { Mdau F un } \\
\mathrm{A} 05686(4 / 6)\end{array}$ & $\begin{array}{c}\text { 24.07.2006; } \\
\text { 49.173819 N, 36.986781 E; } \\
\text { B; MN. }\end{array}$ & $\begin{array}{c}\text { 26.08.2006; } \\
\text { 49.174661 N, 36.995478 E; } \\
\text { AI; MN. }\end{array}$ & 0,5 \\
\hline 47 & $\begin{array}{c}\text { Mdau M ad } \\
\text { A056872 }\end{array}$ & $\begin{array}{c}\text { 24.07.2006; } \\
\text { 49.173819 N, 36.986781 E; } \\
\text { B; MN. }\end{array}$ & $\begin{array}{c}\text { 26.08.2006; } \\
\text { 49.174661 N, 36.995478 E; } \\
\text { AI; MN. }\end{array}$ & 0,5 \\
\hline 48 & $\begin{array}{l}\text { Nnoc F ad } \\
\text { ET00641 }\end{array}$ & $\begin{array}{c}\text { 05.07.2009; } \\
\text { 49.111389 N, 37.403889 E; } \\
\text { B; MN. }\end{array}$ & $\begin{array}{c}\text { 10.07.2009; } \\
\text { 49.106944 N, 37.413333 E; } \\
\text { B; MN. }\end{array}$ & 0,7 \\
\hline 49 & $\begin{array}{l}\text { Nnoc M sad } \\
\text { ET00666 }\end{array}$ & $\begin{array}{c}\text { 07.07.2009; } \\
\text { 49.108333 N, 37.414167 E; } \\
\text { B; MN. }\end{array}$ & $\begin{array}{c}\text { 15.07.2009; } \\
\text { 49.111389 N, 37.403889 E; } \\
\text { B. MN. }\end{array}$ & 1 \\
\hline
\end{tabular}

\section{Records from other locations}

\begin{tabular}{|c|c|c|c|c|}
\hline № & $\begin{array}{l}\text { Species and ring } \\
\text { number }\end{array}$ & $\begin{array}{l}\text { Released (captured) and } \\
\text { ringed: date, point coordi- } \\
\text { nates, season of a year, type } \\
\text { of catching }\end{array}$ & $\begin{array}{c}\text { Recaptured: } \\
\text { date, point coordinates, season } \\
\text { of a year, type of catching }\end{array}$ & Distance, $\mathrm{km}$ \\
\hline 50 & $\begin{array}{c}\text { Nnoc M sad } \\
\text { DT11327 }\end{array}$ & $\begin{array}{c}\text { 08.12.2016 (25.03.2017); } \\
\text { 50.101664 N, 36.280024 E; } \\
\text { H; CR. }\end{array}$ & $\begin{array}{c}31.03 .2018 ; \\
48.85472 \mathrm{~N}, 38.47389 \mathrm{E} ; \\
\text { H; CR. }\end{array}$ & 210 \\
\hline 51 & $\begin{array}{l}\text { Nnoc M sad } \\
\text { DT12690 }\end{array}$ & $\begin{array}{c}\text { 10.07.2017; } \\
\text { 50.224472 N, 36.812028 E; } \\
\text { B; MN. }\end{array}$ & $\begin{array}{c}\text { 17.07.2017; } \\
\text { 50.190694 N, 36.828806 E; } \\
\text { B; MN. }\end{array}$ & 4 \\
\hline
\end{tabular}

